\title{
Model for Self-assessment of the Internal Quality Assurance System in Context of European Standards and Guidelines Requirements
}

\author{
Pavlo Hryhoruk \\ Department of Automated Systems and \\ Modeling in Economics \\ Khmelnytskyi National University \\ Khmelnytskyi, Ukraine \\ violete@ukr.net \\ http://orcid.org/0000-0002-2732-5038
}

\author{
Svitlana Grygoruk \\ Department of Software Engineering \\ Khmelnytskyi National University \\ Khmelnytskyi, Ukraine \\ grygoruk.svitlana@gmail.com \\ http://orcid.org/0000-0003-3047-2271
}

\author{
Mariusz Mazurkiewicz \\ Faculty of Computer Science and \\ Management \\ Wrocław University of Science and \\ Technology \\ Wrocław, Poland \\ mariusz.mazurkiewicz@pwr.edu.pl \\ http://orcid.org/0000-0002-0109-0138
}

\begin{abstract}
The paper deals with the problems of assessing the compliance level of internal quality assurance system with the requirements of European standards and guidelines. The basis of the calculations is the self-assessment procedure based on the composite index evaluation technology. An approach to design a system of initial indicators for calculating the composite index and the procedure for their scaling are proposed. The algorithm for calculating the values of the composite index, which is oriented toward the use of weighted additive convolution, is described. At the same time, it takes into account the nature of the output indicators. The rules for establishing the correspondence between the quantitative and qualitative values of the level of internal quality assurance system are given. Evaluation can be carried out both at the institutional level and at the level of individual academic programme. The article contains examples of indicators and initial indexes that can be used in the assessing procedures for identification the level of internal quality assurance. An example of calculations for the proposed approach is presented. The results of the assessment can be used to identify weak positions in internal quality assurance system, track the dynamics of quality assurance level as a whole, and for its individual components.
\end{abstract}

Keywords - Composite index assessment technology, indicator of quality, self-assessment, Internal Quality Assurance System, scaling, European Standards and Guidelines.

\section{INTRODUCTION}

Higher education, research and innovation play a decisive role in the socio-economic and cultural development of the country, contribute to its economic growth and global competitiveness. The transformational processes taking place in the national higher education system raise the problem of ensuring and improving its quality as one of the key issues of the national educational policy. The integration of the Ukraine's higher education system into the European Higher Education Area (EHEA) by introducing mechanisms for guaranteeing its quality in accordance with the principles and standards of EHEA is one of the main directions of the implementation of the state policy in this area. The Law of Ukraine "On Higher Education" [1] defines the necessity of building in every HEI the internal quality assurance system (IQAS) of higher education as an important part of its strategic management. The existence of such a system is an urgent requirement of time that directs and checks the activities of the institution to ensure the quality of the provision of educational services in accordance with the requirements of higher education standards, the needs and expectations of students and the labor market. An in-depth description of the IQA procedures, the definition of the relationship between the Bologna process and the quality of education are presented in the Standards and Guidelines for Quality Assurance in the European Higher Education Area (ESG 2015) [2]. This document is non-legislative and is of a recommendatory nature. It defines the general framework for quality assurance systems at European, national and institutional levels, promotes a common understanding of the quality assurance of training in all countries and among all stakeholders, supports mutual trust, promoting recognition and mobility; promotes the guarantee and improvement of the quality of higher education in EHEA. These standards play an important role in the development of national and institutional QAS in the EHEA as a key tool for comparing the requirements of national and cross-border quality assurance systems and building the required level of mutual trust. The functioning of IQAS, in accordance with the requirements of the ESG, will contribute to the development of a quality culture and the reestablishment of mutual trust in the quality of higher education between HEIs, labor market and higher education applicants [3].

The components of the external quality assurance system (EQAS) existing in the domestic HEIs partially meet ESG requirements, but don't form a coherent system and should be reformatted in terms of recognition of the leading role of internal systems in ensuring the quality of higher education, as well as the interaction of EQAS and IQAS. The results of the research on introduction of local QAS implemented in 2017 by the International Research Foundation for Educational Policy at 124 Ukrainian HEIs universities of various forms of ownership showed that most of them declared the establishment and operation of IQAS. At the same time, it should be admitted that the main motive for this was not the internal belief in the necessity of their existence, but the external requirements of the EHEA and Law of Ukraine "On Higher Education". This gives grounds to state that this process is predominantly formal in character, and sometimes it takes the form of imitation. The obtained results show that, firstly, far from all the necessary components of local QAS exist, and secondly, the nature of the institutional and normative support of these components and the links 
between them does not give grounds for believing that they are properly coordinated and form the system [4].

The same conclusions can be drawn from the results of the SWOT analysis of the IQAS carried out during the implementation of the International Project Erasmus+ "Quality assurance system in Ukraine: development on the base of ENQA standards and guidelines (QUAERE)" of the Program "KA2: Capacity-building projects in the field of higher education (CBHE)» [5]. In our opinion, an integral part of the IQAS is its self-assessment, in particular assessment of results of the educational activities, strategic planning, monitoring. Such activities are important in the preparation of educational institutions for external quality assurance procedures, in which the accreditation of academic programmes (APs) and institutional accreditation have a key role. The main attention in documents which HEIs prepared for accreditation of AP earlier with assessing the components of the IQAS, was paid to conforming the curriculum with the standard and quantitative indexes - student success, level of their residual knowledge, the number of methodological publications, etc. The orientation of the self-assessment process to the requirements of ESG involves assessing the objectivity of determining the results of training, the adequacy of information, technical, staffing and other kind of provision, both directly to the AP and other aspects of the activity of higher education applicants, as well as monitoring the satisfaction of the educational program by all stakeholders. The result is the determination of the level of achievement of the tasks and the assessment of the success of the program by its developers, as well as the applicants of education and the labor market. This will promote to identify the weaknesses of the AP and develop measures for its improvement, as well as provide to obtain objective information about the quality of a specific $\mathrm{AP}$ and the functioning of the IQAS. We also note that this activity will contribute to the preparation of a self-assessment report for the AP, which is one of the compulsory components of the accreditation process in the EHEA.

\section{LITERATURE REVIEW}

In essence, during any AP accreditation, the evaluation of both the programme itself and the HEI's capacity to realize it is carried out. The analysis of the best international and European accreditation practices, scholar's publications shows a variety of approaches when evaluating educational programs. Articles [6], [7], [8], [9], [10], [11] describe an approach to evaluate APs based on the assessment of learning outcomes. The procedures and tools described show the degree to which learning outcomes are achieved for each programme. The model is common in the sense that it can be applied to any programme with measurable learning outcome. Evaluation objects are the quality of knowledge on a separate discipline, the quality of a separate AP, the effectiveness of the HEI, assessment of certain types of activities of university, for example, social support for students, and others. Assessment tools proposed include, in particular, senior output surveys, alumni survey, written and oral examinations, external advisory panel portfolio, and many others. It is noted, that each tool has some limitations.

The Asean University Network [12] proposes assessment approach to the institutional quality assurance system covers 25 criteria and each criterion is evaluated by a 7-point scale.
The assessment is based on the information provided in the self-assessment report (SAR). On the received results the total institutional rating is calculated. In order for the institution to be accredited, this rating should be not less than 4.

Criteria for assessing APs used by European accreditation agencies, in particular ASIIN, ARACIS, AQAS [13], [14], [15], are aimed on assessing the compliance of programmes with the ESG. As these standards and guidelines requirements are formulated in general terms, agencies develop their own criteria and indicators based on ESG that allow experts to focus on relevant indicators of learning and teaching. Consequently, the criteria should be included in the context of the program, and also take into account the individual goals set by the institution in the SAR. During accreditation, experts evaluate whether the program is able to achieve the stated goals and criteria. To obtain the result of the assessment of compliance with the criteria, a qualitative scale is used which has four levels: not corresponds, partly corresponds, largely corresponds, and fully corresponds.

A similar approach is also presented in [16], which is one of the results of the QUAERE project. Evaluation is carried out within the framework of SAR preparation. The proposed criteria and the indicators developed for their evaluation are mostly qualitative, although quantitative indicators may be used to confirm compliance in a number of cases. For each criterion it is supposed to provide possible evidences of their fulfillment. In our opinion, the disadvantage of the above approaches is a certain subjectivity in the assessment of the IQAS, since they are oriented mainly on the use of qualitative criteria. They characterize the degree of resource provision for AP and aren't quantitative, so they are less formalized. On the other hand, the absence of such formalization doesn't allow to clearly define the boundaries for these criteria levels, which may lead to different evaluation results in same situations. The assessment result will largely be determined by the expert's qualifications and integrity. Quantitative criteria include the compliance of the program with certain, usually established on national level, quantifiable indicators, such as the share of staff with academic degrees, the percentage of information and methodological support for courses, the number of scholar's publications etc. The advantage of quantitative criteria is that they are clear and don't allow misunderstandings, which significantly reduces subjectivity in the QAS assessment and allows us to clearly identify gaps and disadvantages that can't achieve the intended level.

In this paper, we propose an approach to design a system of indicators for the procedure for assessing on this basis, the level and status of the IQAS in accordance with the requirements of the ESG-2015.

\section{Problem Description AND METhodology}

The creating and functioning of the IQAS is impossible without monitoring the quality of education. These procedures should be carried out in accordance in accordance with Article 48 of the Law of Ukraine "On Education" [17]. Effective monitoring activities of HEI should be aimed on collecting and analyzing data on the implementation of a student-centered approach to learning, including the development of the necessary regulatory, informational and 
resource support for the learning, the use of flexible learning trajectories, evaluation of student learning outcomes based on clear and transparent criteria, assessment staff's pedagogical and scientific activities, recognition of competences acquired outside formal educational programs , determination of the degree of consideration of requirements of stakeholders and the labor market to the organization of educational activities. This requires the development of effective monitoring tools as part of the self-governing mechanism and self-organization of IQAS.

One of the key tasks of such monitoring is to identify the level of IQAS. To solve this task, we propose an approach based on such basic conceptual provisions.

1) The calculation procedure for identifying the level of the IQAS should not duplicate the existing systems for assessing the quality of the providing the educational activities of the HEI, but the final result of the assessment should be comparable to the results of the assessment by other approaches.

2) The proposed approach is aimed at self-assessing the quality of IQAS in accordance with the recommendations of the ESG-2015, but it allows modifications based on the views of external experts who take part in accreditation procedure of APs.

3) The values of the indicators on which self-assessment is based should be formalized and not dependent on the subjective perception of the source information for their receipt by the evaluators.

4) The proposed approach should provide adaptation and adjustment to the needs of separate HEI, that allows easy and understandable interpretation of the results.

5) The calculation procedure for identifying the level of the IQAS and its results should be transparent and understandable to a wide range of users.

6) The approach proposed should make it possible to carry out specific cross section and combinations of these sections for: individual indicators; separate APs; separate IQAS subsystems and at the institutional level in general.

To describe the proposed approach, the following interpretation of the concepts of indicator and index is used. Indicator is an element that reflects the level (state) of the QAS or its subsystem in an easily perceived form. The indicator has a nonmetric nature and is measured by the order scale. Index is a quantitatively measured (or evaluated by another way with subsequent quantization of the result) characteristic of one or more properties of educational activity or higher education, reflecting their results. It serves to identify the value of the indicator.

Developing the ideas outlined in [18], [19], it is proposed to measure and identify the level of IQAS according to ESG2015 requirements by following procedure.

1) Development of a system of indicators that characterizes the implementation of the recommendations for each standard of the first part of the ESG-2015.

2) Establishing for each standard set of partial indicators, which in aggregate identify the level of quality assurance under this standard.
3) Calculating for each partial indicator corresponding partial composite index, and identifying the value (state or level) of the this indicator.

4) Calculating for each ESG-2015 Standard the aggregate composite index using the values of partial composite indexes for this standard.

5) Identifying the value of indicator for each standard of ESG-2015 using the value of the correspond aggregate composite index. It reflects the level of quality assurance for this component.

6) Calculation of the value of the comprehensive index by the values of aggregate composite indexes of components of the first part of the ESG-2015.

7) Establishing the general level of IQAS on a qualitative scale by identifying al value of general indicator of the IQAS.

As it follows from the above procedure, assessment the level of IQAS is based on a certain set of initial indexes. The number and content of indexes for each standard is proposed to determine based on the relevant recommendations for each component of ESG. The information or characteristics of the activity, the presence of which in accordance with the Laws of Ukraine "On Education" [17], "On Higher Education" [1] is mandatory (for example, the publicity of certain types of information, the availability of methodological support of courses, etc.), as initial indexes aren't displayed. This simplifies the calculations and makes the results easier to use.

To measure the initial indexes, it is proposed to use two types of scales: dichotomous and metric (quantitative). In our opinion, this reduces the subjectivity in the evaluation. The use of the quantified values of 0 and 1 for the dichotomous scale, which indicate the presence/absence of a certain characteristic, provides the possibility of taking into account/not taking into account the index in their composite convolution. To measure characteristics of educational activity by the metric scale, it is suggested to use ratio. This allows to unify indexes and simplifies their use in the convolution procedure. In our opinion, the use of absolute values of indexes (quantity, volume, etc.) is inconvenient because, firstly, it complicates the definition of the quality level for the IQAS and the interpretation of the final result (it is difficult to determine the "ideal" level for each indicator, high values of the scale for some indexes can reduce the essential the variability of other ones having smaller units of measurement). Secondly, for different HEIs, the same absolute values of the indexes may have different weight, which negatively affects the objectivity of the final result.

The use of ordinal scales to measure indexes at this procedure is not feasible, since this significantly increases the subjectivity of assessments. Typically, such measurements use the involvement of experts, which complicates the process of data collection and will increase its duration in time. It also requires additional calculations (coordination of expert opinions, the construction of generalized expert assessments, etc.). Another disadvantage is that this significantly complicates the convolution of indexes (ranked data are not metric and require special methods for their quantification and further processing). Determination of the quantitative level of a partial composite index is carried out by the method for a weighted linear 
convolution. The weight of each component can be determined either by expert or statistical analysis of these indexes. The approach proposed is oriented to the selfassessment of the IQAS for HEI and doesn't involve the external experts, so the number of indicators and their weights can be determined by each HEI independently.

To identify the qualitative level of the IQAS based on the constructed indexes for each standard of the first part of the ESG-2015 and the overall quality of the IQAS, we use the quality scale provided in [16]. To design a model that implements the above-mentioned procedure for assessing the level of the IQAS, we introduce the following notation:

$S_{i}-i$-th Standard of ESG-2015, $i=1 . .9 ; m_{i}$ - number of indicators for Standard $S_{i} ; I_{i, j}^{Q}-j$-th partial indicator for Standard $S_{i}, j=1 . . m_{i} ; I_{i, j}^{N}-j$-th partial composite index for $S_{i}$; $k_{i, j}$ - number of initial indexes to identify indicator $I_{i, j}^{Q}$ and involve to the calculation of $I_{i, j}^{N} ; u_{i, j}$ - weight of partial composite index $I_{i, j}^{N}, \sum_{j=1}^{m_{i}} u_{i, j}=1 ; P_{i, j, s}-s$-th index for $j$ th indicator for Standard $S_{i} ; w_{i, j, s}-$ weight of index $P_{i, j, s}$; $s=1 . . \quad k_{i, j}, \quad \sum_{s=1}^{k_{i, j}} w_{i, j, s}=1 ; \quad I_{i}^{Q}-$ aggregate indicator for Standard $S_{i} ; I_{i}^{N}$ - aggregate composite index for Standard $S_{i}$; $v_{i}$ - weight of aggregate composite index $I_{i}^{N}$ for Standard $S_{i}, \sum_{i=1}^{9} v_{i}=1 ; I_{I Q A S}^{Q}-$ general indicator for IQAS; $I_{I Q A S}^{N}-$ comprehensive index for IQAS.

Calculation of indexes is carried out by such rules. For the partial indexes following formula is used:

$$
I_{i, j}^{N}=\sum_{s=1}^{k_{i, j}} w_{i, j, s} P_{i, j, s}
$$

Aggregate composite index is calculated by the formula:

$$
I_{i}^{N}=\sum_{j-1}^{m_{i}} u_{i, j} I_{i, j}^{N}
$$

Comprehensive index is calculated by the formula:

$$
I_{I Q A S}^{N}=\sum_{i=1}^{9} v_{i} I_{i}^{N}
$$

Identifying the levels of indicators $I_{i, j}^{Q}, I_{i}^{Q}, I_{I Q A S}^{Q}$ by the values of appropriate composite indexes $I_{i, j}^{N}, I_{i}^{N}, I_{I Q A S}^{N}$ is carried out in accordance with Table 1. To rich this aim the modified Harrington's scale is used.
TABLE I. TRANSITION RULES FROM NUMERICAL VALUES OF COMPOSITE INDEX TO QUALITATIVE LEVELS OF THE INDICATOR

\begin{tabular}{|l|l|l|}
\hline $\begin{array}{c}\text { Range of values by } \\
\text { composite index }\end{array}$ & \multicolumn{1}{|c|}{$\begin{array}{c}\text { Quality level by } \\
\text { modified Harrington's } \\
\text { scale }\end{array}$} & \multicolumn{1}{|c|}{ Indicator's value } \\
\cline { 1 - 2 } $0.00 . .0 .35$ & Very badly & Not corresponds \\
\hline $0.36 . .0 .46$ & Badly & Corresponds fully \\
\hline $0.47 . .0 .63$ & Satisfactorily & Corresponds largely \\
\hline $0.64 . .0 .80$ & Good & Corresponds fully \\
\hline $0.81 . .1 .00$ & Very good & \multicolumn{1}{|l}{} \\
\hline
\end{tabular}

\section{RESULTS AND DISCUSSIONS}

Let's consider the application of the proposed approach on the example of the evaluation of two APs and the IQAS of some virtual HEI. The research was conducted during 2017-2018 as part of the QUAERE project. For calculations we have developed a set of indicators for each of the 9 standards of the first part of the ESG-2015. Each Standard contained from 3 to 7 indicators. In total 37 indicators were developed. An example of indicators for the first two ESG-

\begin{tabular}{|c|c|c|}
\hline Standard & $\begin{array}{c}\text { Designation of } \\
\text { the indicator }\end{array}$ & Title of Standard/Indicator \\
\hline \multirow{5}{*}{$S_{1}$} & $I_{1}^{Q}$ & Policy for quality assurance \\
\hline & $I_{1,1}^{Q}$ & Degree of normative support of IQAS. \\
\hline & $I_{1,2}^{Q}$ & $\begin{array}{l}\text { The degree of involvement of internal } \\
\text { and external stakeholders to shape a } \\
\text { quality assurance policy }\end{array}$ \\
\hline & $I_{1,3}^{Q}$ & Degree of ensuring academic integrity \\
\hline & $I_{1,4}^{Q}$ & $\begin{array}{l}\text { The degree of publicity of the quality } \\
\text { assurance policy }\end{array}$ \\
\hline \multirow{5}{*}{$S_{2}$} & $I_{2}^{Q}$ & Design and approval of programmes \\
\hline & $I_{2,1}^{Q}$ & $\begin{array}{l}\text { The degree of availability of normative } \\
\text { support for the mechanism of } \\
\text { development and approval of AP }\end{array}$ \\
\hline & $I_{2,2}^{Q}$ & $\begin{array}{l}\text { The degree of use of external and internal } \\
\text { expertise of AP }\end{array}$ \\
\hline & $I_{2,3}^{Q}$ & $\begin{array}{l}\text { Degree of the AP compliance with the } \\
\text { requirements of students and external } \\
\text { stakeholder }\end{array}$ \\
\hline & $I_{2,4}^{Q}$ & Degree of qualification of AP developers \\
\hline
\end{tabular}
2015 Standards is given in Table 2.

TABLE II. EXAMPLE OF INDICATORS

To determine the level of each indicator, a set of initial indexes was designed, for each indicator their number was different and ranged from 6 to 13 units. The total number of initial indexes was 410 . The overwhelming majority of the proposed indexes reflected the presence or absence of a separate component for the assessment of the appropriate indicator, and therefore measured on a dichotomous scale. This has greatly simplified the data collection process. An example of indexes for the first indicator of the first Standard of ESG-2015 is shown in Table 3, and their values are presented in Table 4. It also contains the value of the composite index $I_{1,1}^{N}$ as well as the value of the corresponding indicator $I_{1,1}^{Q}$. All values are calculated for APs, as well as for the IQAS as a whole. 
TABLE III. EXAMPLE OF INITIAL INDEXES

\begin{tabular}{|c|c|c|}
\hline $\begin{array}{l}\text { Designation } \\
\text { of the initial } \\
\text { index }\end{array}$ & Title of the initial index & Scale \\
\hline$P_{1,1,1}$ & $\begin{array}{l}\text { Availability of document regulating } \\
\text { the functioning of the IQAS. }\end{array}$ & Dichotomous \\
\hline$P_{1,1,2}$ & $\begin{array}{l}\text { The presence of document regulating } \\
\text { the functioning of a special department } \\
\text { or person within the IQAS. }\end{array}$ & Dichotomous \\
\hline$P_{1,1,3}$ & $\begin{array}{l}\text { Availability of document regarding the } \\
\text { organization of the IQAS. }\end{array}$ & Dichotomous \\
\hline$P_{1,1,4}$ & $\begin{array}{l}\text { Availability of documents regulating } \\
\text { the involvement of external } \\
\text { stakeholders to shape an IQAS policy }\end{array}$ & Dichotomous \\
\hline$P_{1,1,5}$ & $\begin{array}{l}\text { Availability of documents regulating } \\
\text { the involvement of students to shape } \\
\text { an IQAS policy. }\end{array}$ & Dichotomous \\
\hline$P_{1,1,6}$ & $\begin{array}{l}\text { The existence of a procedure for } \\
\text { detecting and preventing violations of } \\
\text { academic integrity in the student's } \\
\text { activity. }\end{array}$ & Dichotomous \\
\hline$P_{1,1,7}$ & $\begin{array}{l}\text { The existence of a procedure for } \\
\text { detecting and preventing violations of } \\
\text { academic integrity in scientific and } \\
\text { methodical publications of academic } \\
\text { staff. }\end{array}$ & Dichotomous \\
\hline$P_{1,1,8}$ & $\begin{array}{l}\text { The presence of a procedure for the } \\
\text { detection and prevention of violations } \\
\text { of academic integrity in educational } \\
\text { activities. }\end{array}$ & Dichotomous \\
\hline$P_{1,1,9}$ & $\begin{array}{l}\text { Availability of documents reflecting } \\
\text { the policy regarding the IQA at the } \\
\text { level of graduate departments. }\end{array}$ & Dichotomous \\
\hline
\end{tabular}

TABLE IV. EXAMPLE OF INITIAL DATA AND CALCULATION OF PARTIAL COMPOSITE INDEX AND CORRESPONDING INDICATOR

\begin{tabular}{|l|l|l|l|l|}
\hline \multirow{2}{*}{$\begin{array}{c}\text { Index/ } \\
\text { Indicator }\end{array}$} & \multirow{2}{*}{$\begin{array}{c}\text { Weight } \\
\text { of index }\end{array}$} & \multicolumn{3}{|c|}{ Value } \\
\cline { 3 - 5 }$P_{1,1,1}$ & 0.18 & 1 & 1 & 1 \\
\hline$P_{1,1,2}$ & 0.14 & 1 & 1 & 1 \\
\hline$P_{1,1,3}$ & 0.16 & 1 & 1 & 1 \\
\hline$P_{1,1,4}$ & 0.09 & 0 & 0 & 0 \\
\hline$P_{1,1,5}$ & 0.13 & 1 & 1 & 1 \\
\hline$P_{1,1,6}$ & 0.11 & 1 & 1 & 1 \\
\hline$P_{1,1,7}$ & 0.08 & 0 & 0 & 0 \\
\hline$P_{1,1,8}$ & 0.07 & 1 & 1 & 1 \\
\hline$P_{1,1,9}$ & 0.04 & 0 & 1 & 1 \\
\hline$I_{1,1}^{N}$ & - & 0.79 & 0.83 & 0.83 \\
\hline$I_{1,1}^{Q}$ & - & $\begin{array}{l}\text { Corresponds } \\
\text { largely }\end{array}$ & $\begin{array}{l}\text { Corresponds } \\
\text { fully }\end{array}$ & Corresponds fully \\
\hline
\end{tabular}

Table 5 presents the results of calculations of the values of partial composite indexes. the corresponding levels of indicators. the value of the aggregate composite index for the first Standard and the corresponding level of the aggregate indicator. Table 6 shows the values of the aggregate composite indexes for the Standards $S_{1}-S_{9}$, the corresponding values of aggregate indicators, as well as the results of calculating the comprehensive index and its corresponding indicator value.
TABLE V. EXAMPLE OF CALCULATION OF PARTIAL COMPOSITE INDEXES AND CORRESPONDING INDICATORS FOR STANDARD $S_{1}$

\begin{tabular}{|c|c|c|c|c|}
\hline \multirow{2}{*}{$\begin{array}{l}\text { Index/ } \\
\text { Indicator }\end{array}$} & \multirow{2}{*}{$\begin{array}{l}\text { Weight } \\
\text { of index }\end{array}$} & \multicolumn{3}{|c|}{ Value } \\
\hline & & for first $A P$ & for second $A P$ & $\begin{array}{c}\text { for IQAS in } \\
\text { general }\end{array}$ \\
\hline$I_{1,1}^{N}$ & 0.29 & 0.79 & 0.83 & 0.83 \\
\hline$I_{1,1}^{Q}$ & - & $\begin{array}{l}\text { Corresponds } \\
\text { largely }\end{array}$ & $\begin{array}{l}\text { Corresponds } \\
\text { fully }\end{array}$ & $\begin{array}{l}\text { Corresponds } \\
\text { fully }\end{array}$ \\
\hline$I_{1,2}^{N}$ & 0.25 & 0.82 & 0.77 & 0.79 \\
\hline$I_{1,2}^{Q}$ & - & $\begin{array}{l}\text { Corresponds } \\
\text { fully }\end{array}$ & $\begin{array}{l}\text { Corresponds } \\
\text { largely }\end{array}$ & $\begin{array}{l}\text { Corresponds } \\
\text { largely }\end{array}$ \\
\hline$I_{1,3}^{N}$ & 0.27 & 0.60 & 0.60 & 0.60 \\
\hline$I_{1,3}^{Q}$ & - & $\begin{array}{l}\text { Corresponds } \\
\text { partly }\end{array}$ & $\begin{array}{l}\text { Corresponds } \\
\text { partly }\end{array}$ & $\begin{array}{l}\text { Corresponds } \\
\text { partly }\end{array}$ \\
\hline$I_{1,4}^{N}$ & 0.19 & 0.78 & 0.84 & 0.81 \\
\hline$I_{1,4}^{Q}$ & - & $\begin{array}{l}\text { Corresponds } \\
\text { largely }\end{array}$ & $\begin{array}{l}\text { Corresponds } \\
\text { fully }\end{array}$ & $\begin{array}{l}\text { Corresponds } \\
\text { fully }\end{array}$ \\
\hline$I_{1}^{N}$ & - & 0.74 & 0.75 & 0.75 \\
\hline$I_{1}^{Q}$ & - & $\begin{array}{l}\text { Corresponds } \\
\text { largely }\end{array}$ & $\begin{array}{l}\text { Corresponds } \\
\text { largely }\end{array}$ & $\begin{array}{l}\text { Corresponds } \\
\text { largely }\end{array}$ \\
\hline
\end{tabular}

TABLE VI. EXAMPLE OF FinAl RESUlts of CALCULATIONS

\begin{tabular}{|c|c|c|c|}
\hline \multirow{2}{*}{$\begin{array}{l}\text { Index/ } \\
\text { Indicator }\end{array}$} & \multicolumn{3}{|c|}{ Value } \\
\hline & for first $A P$ & for second $A P$ & for IQAS in general \\
\hline$I_{1}^{N}$ & 0.74 & 0.75 & 0.75 \\
\hline$I_{1}^{Q}$ & $\begin{array}{l}\text { Corresponds } \\
\text { largely }\end{array}$ & $\begin{array}{l}\text { Corresponds } \\
\text { largely }\end{array}$ & Corresponds largely \\
\hline$I_{2}^{N}$ & 0.69 & 0.65 & 0.67 \\
\hline$I_{2}^{Q}$ & $\begin{array}{l}\text { Corresponds } \\
\text { largely }\end{array}$ & $\begin{array}{l}\text { Corresponds } \\
\text { largely }\end{array}$ & Corresponds largely \\
\hline$I_{3}^{N}$ & 0.69 & 0.65 & 0.67 \\
\hline$I_{3}^{Q}$ & $\begin{array}{l}\text { Corresponds } \\
\text { largely }\end{array}$ & $\begin{array}{l}\text { Corresponds } \\
\text { largely }\end{array}$ & Corresponds largely \\
\hline$I_{4}^{N}$ & 0.69 & 0.68 & 0.69 \\
\hline$I_{4}^{Q}$ & $\begin{array}{l}\text { Corresponds } \\
\text { largely }\end{array}$ & $\begin{array}{l}\text { Corresponds } \\
\text { largely }\end{array}$ & Corresponds largely \\
\hline$I_{5}^{N}$ & 0.63 & 0.50 & 0.56 \\
\hline$I_{5}^{Q}$ & $\begin{array}{l}\text { Corresponds } \\
\text { partly }\end{array}$ & $\begin{array}{l}\text { Corresponds } \\
\text { partly }\end{array}$ & Corresponds partly \\
\hline$I_{6}^{N}$ & 0.53 & 0.62 & 0.59 \\
\hline$I_{6}^{Q}$ & $\begin{array}{l}\text { Corresponds } \\
\text { partly }\end{array}$ & $\begin{array}{l}\text { Corresponds } \\
\text { partly }\end{array}$ & Corresponds partly \\
\hline$I_{7}^{N}$ & 0.69 & 0.77 & 0.74 \\
\hline$I_{7}^{Q}$ & $\begin{array}{l}\text { Corresponds } \\
\text { largely }\end{array}$ & $\begin{array}{l}\text { Corresponds } \\
\text { largely }\end{array}$ & Corresponds largely \\
\hline$I_{8}^{N}$ & 0.63 & 0.68 & 0.64 \\
\hline$I_{8}^{Q}$ & $\begin{array}{l}\text { Corresponds } \\
\text { partly }\end{array}$ & $\begin{array}{l}\text { Corresponds } \\
\text { largely }\end{array}$ & Corresponds largely \\
\hline$I_{9}^{N}$ & 0.96 & 0.91 & 0.94 \\
\hline$I_{9}^{Q}$ & $\begin{array}{l}\text { Corresponds } \\
\text { fully }\end{array}$ & $\begin{array}{l}\text { Corresponds } \\
\text { fully }\end{array}$ & Corresponds fully \\
\hline$I_{I Q A S}^{N}$ & 0.67 & 0.64 & 0.65 \\
\hline$I_{I Q A S}^{Q}$ & $\begin{array}{l}\text { Corresponds } \\
\text { largely }\end{array}$ & $\begin{array}{l}\text { Corresponds } \\
\text { largely }\end{array}$ & Corresponds largely \\
\hline
\end{tabular}


An analysis of the results of the calculations obtained shows that for most aggregate indicators, the level of compliance of quality assurance with the ESG recommendations has the value "Corresponds largely". This takes place both for the APs and for the IQAS as a whole. However, for the S5 Standard, which reflects the requirements for staff support of educational activities, the indicator value is "Corresponds partly". Consequently, HEI's management should pay attention to improving the situation in this area, given that staffing is one of the most important in APs accreditation

\section{CONCLUSIONS}

The development of an internal quality assurance system of HEIs remains as one of the most urgent tasks of reforming and developing the Ukraine's higher education system, in view of the desire to become a full partner in the EHEA. Therefore, an important task is to assess the level of compliance of the IQAS with the requirements of the EHEA, which are reflected in the ESG. The scientific novelty of the conducted studies is a procedure for the implementation of such an assessment. Calculations are based on the set of initial indexes, that are determined in accordance with Standards of first part of ESG, that reflect the requirements to the IQAS. It is proposed to determine the number and content of indexes based on the relevant recommendations for each Standard. Initial indexes are used to calculate a set of composite indexes, that serves as the foundation to identify levels of appropriate quality indicators. The paper describes the rules for identifying the qualitative level of the indicator for the corresponding numerical value of the composite index. The use of both quantitative indexes and qualitative indicators that characterize the level of the IQAS has the advantage that the quantitative values allow the comparison of values, in particular, when evaluating various educational programs, tracking the dynamics of changes in the values of calculated indicators, identifying deficiencies and gaps in quality assurance. Indicators are used for meaningful interpretation of the results obtained by defining the level of the IQAS for the ESG recommendations both in general and for the separate quality assurance components. The article presents the practical implementation of the proposed approach. Examples to shape a set of initial indexes, system of indicators, interpretation of received results are presented in the paper. The approach proposed can be adapted for application to other sets of initial indexes without changing the calculation algorithm and rules for interpreting the result.

\section{ACKNOWLEDGMENT}

This study was supported by International Project Erasmus+ № 562013-EPP-1-2015-1-PLEPPKA2-CBHE-SP "Quality assurance system in Ukraine: development on the base of ENQA standards and guidelines (QUAERE)"

\section{REFERENCES}

[1] Verkhovna Rada of Ukraine (2014, Jul. 1). Law of Ukraine "On Higher Education". [Online]. Available: https://zakon.rada.gov.ua/laws/show/1556-18?lang=uk

[2] Ministerial Conference in Yerevan (2015, May 14-15). Standards and Guidelines for Quality Assurance in the European Higher Education
Area (ESG). [Online]. Available: https://enqa.eu/wpcontent/uploads/2015/11/ESG_2015.pdf

[3] D. Shchegliuk, "The role of the self-assessment report for the educational program in the systems of internal and external quality assurance of higher education", International Scientific Journal of Universities and Leadership, no. 2 (6), 2018. [Online]. Available: https://ul-journal.org/index.php/journal/article/download/79/75. Accessed on: July 7, 2019. Doi: https://doi.org/10.31874/2520-67022018-6-2-34-44

[4] T. V. Finikov, and V. I. Tereshchuk (eds), Implementation of Local Quality Management Systems at Ukrainian Universities: An Analytical Report. Kyiv, Ukraine: Taxon, 2018.

[5] V.A. Bugrov et.al, Experience of Participation of Taras Shevchenko Kyiv National University in the Development of the Quality Assurance System of Higher Education in Ukraine (based on the QUAERE project). Kyiv, Ukraine: VPTS «Kyivs'kyi Universytet», 2018.

[6] R. A. K. Mehdi, and M. S. AbouNaaj, "Academic Program Assessment: A Case Study of a Pragmatic Approach", Creative Education, vol. 4, no. 1, pp. 71-81, 2013. Doi: http://dx.doi.org/10.4236/ce.2013.41010

[7] H. M. Harmanani, "An outcome-based assessment process for accrediting computing Programmes", European Journal of Engineering Education, vol.42, no. 6, pp. 844-859, 2017. Doi: https://doi.org/10.1080/03043797.2016.122678.

[8] M. S. Al-Homoud and S. A. Said, "Academic Program Assessment and Accreditation: KFUPM Experience", 2015. [Online]. Available: https://www.researchgate.net/publication/228545522. Accessed on: July $10,2019$.

[9] R. Jayaprabha, R. Jeyanthi, T. Komalavalli, and P.V. Girija, "An Empirical Study on Measuring Attainment of Course Outcomes and Program Outcomes of B.Ed. Program as Per Self-Assessment ReportJune 2015", International Journal of Social Science and Humanities Research, vol. 7, no. 1, pp. 522-528, January - March 2019.

[10] R. A. Wahsheh, "Assessment of Academic Programs' Quality from Student Perspective at Najran University", International Research in Education, vol. 5, no. 1, pp. 121-142, 2017. doi:10.5296/ire.v5i1.10889.

[11] K. Mohiudddin, A. Islam, S. Mohd, and M. Shariff, "Evaluation of an Academic Program: The Case of Computing Accreditation Commission Framework in Higher Education", International Journal of Emerging Technologies in Learning (iJET), vol. 14, no. 11, pp. 7091, June 2019. Doi: 10.3991/ijet.v14i11.10178

[12] Asean University Network Quality Assurance: Guide to Aun-Qa Assessment at Institutional Level. Bangkok, Thailand: Asean University Network, 2016.

[13] Criteria for the Accreditation of Degree Programmes - ASIIN Quality Seal Engineering, Informatics, Architecture, Natural Sciences, Mathematics, individually and in combination with other Subject Areas. Dusseldorf, Germany: ASIIN, 2016. [Online]. Available: https://www.asiin.de/en/quality-management/accreditation-degreeprogrammes/quality-criteria.html. Accessed on: July 10, 2019.

[14] G. H. Szabo, "Approaches for Internal Evaluation of Universities in a New Public Responsibility Framework of ESG 2015", Quality Assurance Review for Higher Education, 7(2), pp. 33-51, 2017.

[15] Criteria \& Indicators for programme accreditation. [Online]. Available: $\quad$ https://www.aau.org/haqaa/wpcontent/uploads/2016/10/criteria-indicators-programme-accreditationAQAS.pdf. Accessed on: July 10, 2019.

[16] V. A. Bugrov et.al, "Accreditation of Educational Programs (based on QUAERE project materials : methodical manual". Kyiv, Ukraine: VPTS "Kyivs'kyi Universytet", 2018.

[17] Verkhovna Rada of Ukraine (2017, Sep. 7). Law of Ukraine "On Education". [Online]. https://zakon.rada.gov.ua/laws/show/2145-19

[18] P.M. Hryhoruk, and S.S. Grygoruk, "An approach to assess the state of the HEI's quality assurance system in context of requirements and recommendations of ESG", in Proceedings of VII International Scientific Conference on Ukrainian-Polish Scientific Dialogues, Khmelnytskyi, 2017, pp. 208-209.

[19] S.S. Grygoruk, and P.M. Hryhoruk, "Model for assessing the internal quality assurance system\}, in Proceedings of IV International Scientific Conference on Mechanisms, Strategies, Models and Technologies of Economic Systems Management in condition of integration processes: theory, methodology and practice, Khmelnytskyi, 2017, pp. 203-205. 